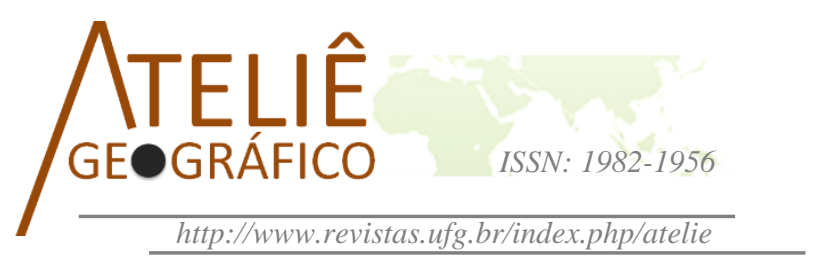

\title{
Produção agrícola no estado do Mato Grosso e a relação entre o agronegócio e as cidades: o caso de Lucas do Rio Verde e Sorriso
}

\author{
Agricultural production in the State of Mato Grosso and the \\ relationship between agribusiness and cities: the case of \\ Lucas do Rio Verde and Sorriso
}

\author{
Producción agrícola en el estado de Mato Grosso y la \\ relación entre el agronegocio y las ciudades: el caso de \\ Lucas do Rio Verde y Sorriso
}

\author{
Eduardo von Dentz \\ Universidade Federal de Santa Catarina \\ eduardovondentz@hotomail.com
}

\begin{abstract}
Resumo
Nas últimas duas décadas, principalmente, a produção agrícola do estado do Mato Grosso teve uma grande evolução, tendo transformado o estado no maior produtor nacional de grãos, com destaque para as culturas de soja, milho, algodão e girassol. Ao passo que a produção agrícola cresceu, foi se percebendo uma estreita relação entre o agronegócio e as cidades. Por essas questões, o objetivo desse artigo é demonstrar a dinâmica recente da produção agrícola do estado do Mato Grosso e a relação do agronegócio com as cidades. Metodologicamente o artigo foi construído através da revisão bibliográfica, levantamento de dados e trabalhos de campo. Como resultados principais, pode-se dizer que o potencial agrícola do Mato Grosso cresceu muito em função dos incentivos das políticas de Estado e do favorecimento das condições edafoclimáticas que as terras do Mato Grosso oferecem. Na relação entre o agronegócio e as cidades, é possível afirmar que a antiga sobreposição ou submissão de um em relação ao outro não pode ser aplicada a este cenário, haja vista que identificamos uma relação de complementariedade entre o agronegócio e as cidades.

Palavras chave: Produção agrícola; Agronegócio; Cidade; Mato Grosso.
\end{abstract}

\begin{abstract}
Especially in the last two decades the agricultural production in the State of Mato Grosso has undergone a great evolution, having transformed the state into the largest national grain producer with emphasis on soy, corn, cotton and sunflower crops. As agricultural production grew, a close relationship was found between agribusiness and cities. For these reasons this article's objective is to demonstrate the recent
\end{abstract}


agricultural production dynamics in the State of Mato Grosso and the relationship between agribusiness and cities. Methodologically the article was constructed through bibliographic review, data collection and fieldwork. As main results, it can be said that the agricultural potential of Mato Grosso increased greatly due incentives of the State policies and the favorable edaphoclimatic conditions that Mato Grosso lands offer. In the relationship between agribusiness and cities it is possible to affirm that the old overlap or submission of one to the other can not be applied to this scenario since was identified a complementary relationship between agribusiness and cities.

Keywords: Agriculture production; Agribusiness; City; Mato Grosso.

\section{Resumen}

En las dos últimas décadas, principalmente, la producción agrícola del estado de Mato Grosso tuve una gran evolución, tiendo transformado el estado en el mayor productor nacional de granos, con destaque para las culturas de soya, maíz, algodón y girasol. Al paso que la producción agrícola creció, fue se percibiendo una estrecha relación entre el agronegocio y las ciudades. Por esas cuestiones, el objetivo de este articulo es demonstrar la dinámica reciente de la producción agrícola del estado de Mato Grosso y la relación del agronegocio con las ciudades. Metodológicamente el artículo fue construido con la revisión bibliográfica, levantamiento de datos y trabajos de campo. Como resultados principales, se puede decir que el potencial agrícola de Mato Grosso creció mucho en función de los incentivos de las políticas de Estado y del favorecimiento de las condiciones edafoclimáticas que las tierras de Mato Grosso ofrecen. En la relación entre el agronegocio y las ciudades, es posible afirmar que la antigua sobreposición o sumisión de uno con relación al otro no se puede aplicar a este senario, porque identificamos una relación de complementariedad entre el agronegocio y las ciudades.

Palabras clave: Producción agrícola; Agronegocio; Ciudades; Mato Grosso.

\section{Introdução}

A formação econômica e social (Santos, 1977) do Brasil, se configura na base para o que mais tarde, pós década de 1960 , resultou nas mudanças de ordem técnica ocorridas em todos os setores da economia. De acordo com Santos (1994) as transformações ocasionadas pelo avanço do progresso técnico, científico e informacional nas atividades econômicas do Brasil trouxeram para os setores econômicos aquilo que pode ser considerado moderno. No setor agrícola, Graziano da Silva (1998) aponta que os maiores avanços ocorreram a partir dos impulsos das políticas keynesianas do pósguerra (1980), quando acontece a integração da agricultura com outros setores da economia.

Ao estender esse tema até as transformações ocorridas no estado do Mato Grosso, pode-se afirmar que tais transformações, sobretudo na base técnica e produtiva da agricultura, bem como aponta Dentz (2018), levou o potencial desse estado na produção de grãos crescer substancialmente, sobretudo nas últimas duas décadas. Ademais, além dos avanços técnicos, outros fatores foram importantes para o desenvolvimento da agricultura altamente mecanizada nesse estado, dentre os quais citamos: relevo plano e favorável a mecanização em boa parte das terras agrícolas do estado, condições edafoclimáticas favoráveis (duas estações bem definidas), grande 
incentivo do governo através de políticas públicas específicas e crédito subsidiado e atração de agricultores de outras partes do Brasil para o estado devido as condições favoráveis citadas (Bernardes, 2015; Frederico, 2008; Dentz, 2018). Em outras palavras, o capital encontrou motivos e maneiras estratégicas de se instalar no Mato Grosso devido o potencial agrícola a ser explorado em suas terras.

Os dados desse artigo apontam que atualmente o potencial agrícola do estado do Mato Grosso é surpreendente, podendo ser considerado o maior produtor nacional de grãos. O destaque dos grãos produzidos no estado se dá nas culturas de soja, milho, algodão, girassol, feijão e outros, sendo a soja o carro-chefe da agricultura matogrossense. Além disso, a produção de suínos, aves e bovinos ocupa papel importante na economia do estado, haja vista que o fornecimento de matéria-prima (soja e milho) para investir na criação da proteína animal (suínos, aves e bovinos) é abundante (Bernardes, 2015).

Em função de muitos outros trabalhos, como Frederico (2008), Bernardes (2015), Elias (2011) e Dentz (2018) já terem demonstrado o processo que levou o estado do Mato Grosso a se transformar na maior força do agronegócio nacional, iremos, neste artigo, focar nos dados que apresentam o cenário atual da produção agrícola do estado. No entanto, quando se fala do agronegócio no estado do Mato Grosso, inevitavelmente é preciso dizer que ele não emanou sozinho, mas junto dele se desenvolveu um conjunto de cidades (centros urbanos) com a finalidade principal de oferecer os serviços demandados pelo agronegócio.

Por essas razões, ao mesmo tempo em que neste artigo o objetivo é demonstrar a dinâmica recente da produção agrícola do estado do Mato Grosso, também procuramos demonstrar a relação do agronegócio com as cidades. Trata-se de um assunto que não pode ser abordado separadamente, pois o agronegócio do qual se fala é intimamente ligado com a estrutura que as cidades dos seus arredores oferecem para manter o pleno funcionamento da produção agrícola. Assim, para conseguir os resultados que vão ao encontro de atender esse objetivo, usamos de três passos metodológicos: revisão bibliográfica, levantamento de dados e trabalhos de campo.

No que segue, o primeiro item aborda sobre a dinâmica da produção agrícola no estado do Mato Grosso e o segundo item aborda sobre a relação do agronegócio com as cidades do estado do Mato Grosso. Por fim, apresentamos as considerações finais.

\section{A dinâmica da produção agrícola no estado do Mato Grosso}

A produção agrícola do estado do Mato Grosso é bastante representativa, sendo que o estado desponta no cenário nacional como o maior produtor de soja, milho, algodão e girassol. A importância é ainda maior quando se considera apenas o cenário da região Centro-Oeste do Brasil, haja vista que na região Centro-Oeste o estado do Mato Grosso é responsável por pelo menos $60 \%$ da produção agrícola, o que dá uma ideia da dimensão da sua importância. Neste sentido, a figura 01 apresenta a série histórica da área plantada de grãos no estado e na região Centro-Oeste. 


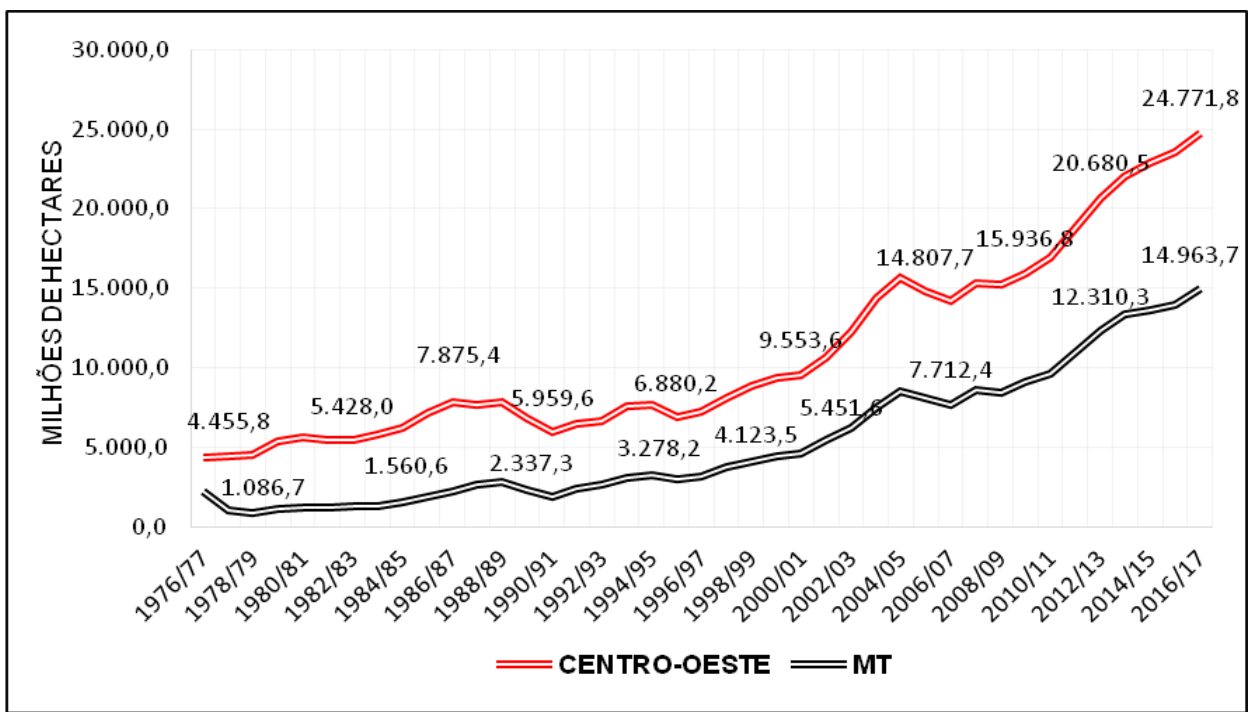

Figura 01: Série histórica de área plantada de grãos ${ }^{1}$ no estado do Mato Grosso e região CentroOeste em milhões de hectares (safra 1976/77 a 2016/17).

Fonte: Conab, 2017. Elaborado pelo autor.

De acordo com a figura 01, a área plantada de grãos no estado do Mato Grosso teve um crescimento significativo nos últimos anos. Conforme apontam os dados da Conab, no final da década de 1970 o estado do Mato Grosso já plantava em torno de um milhão de hectares de grãos. Esse índice se manteve estagnado no início da década de 1980. A partir de 1990, com a liberalização da economia, o avanço das políticas neoliberais, os incentivos creditícios, a entrada das tradings no sistema de financiamento agrícola e as pesquisas desenvolvidas sobre adaptação genética da soja para o Cerrado, a área plantada de grãos no estado entra numa curva de crescimento que perdura da safra 1990/91 até a safra 2004/05, sem interrupção. Nas safras de 2007 e 2008 houve uma leve queda na área plantada, devido ao início da crise internacional de 2008, que fez diminuir o ritmo do crescimento. No entanto, pode-se dizer que do final da década de 1970 (1976/77) até a última safra, 2016/17, o estado do Mato Grosso saiu do plantio de pouco mais de um milhão de hectares para quase 15 milhões de hectares. Esses dados mostram que a área plantada de grãos no estado aumentou quinze vezes em quarenta anos. Ademais, a área de grãos plantada no estado do Mato Grosso representa cerca de $60 \%$ da área plantada em toda a região Centro-Oeste.

No entanto, não foi apenas o crescimento da área plantada que transformou o estado do Mato Grosso no que atualmente se configura no maior produtor de grãos do país. Na figura 02 pode ser verificada a evolução na produtividade dos grãos na região Centro-Oeste e no estado do Mato Grosso ao longo do tempo.

\footnotetext{
${ }^{1}$ Envolve as culturas de milho, soja, algodão, sorgo, centeio, amendoim, feijão, arroz e milheto.
} 


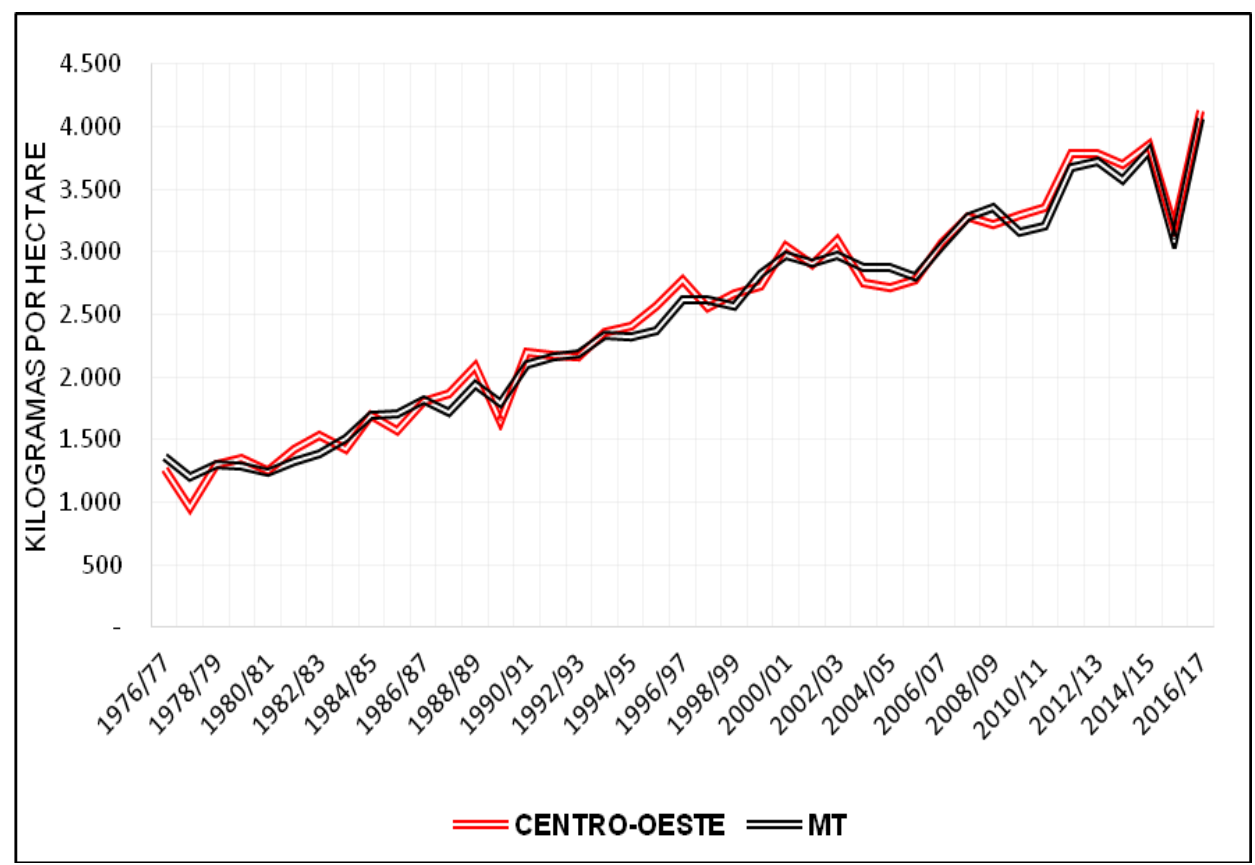

Figura 02: Série histórica de produtividade dos grãos no estado do Mato Grosso e na região Centro-Oeste em kg/ha (safra 1976/77 a 2016/17).

Fonte: Conab, 2017. Elaborado pelo autor.

Como aponta a figura 02, a produtividade de grãos no estado do Mato Grosso e na região Centro-Oeste do Brasil teve uma significativa evolução, tendo em vista os 40 anos em análise na figura 02 . Antes de analisar os números da produtividade de grãos em si, vale salientar que, ao longo do período, não há uma diferença significativa entre a produtividade do estado do Mato Grosso e da região Centro-Oeste, em parte, pela razão de $60 \%$ dos grãos da região Centro-Oeste serem produzidos no estado do Mato Grosso, como apontado na figura 01. No que se refere aos números da produtividade, na safra 1976/77 a mesma girava em torno de $1.400 \mathrm{~kg} / \mathrm{ha}$. Embora pequenas variações tenham ocorrido ao longo do tempo, geralmente em função de intempéries climáticas ou em função do baixo investimento nas lavouras - que pode ocorrer, por exemplo, devido ao baixo preço da comercialização dos grãos - pode-se afirmar que houve uma significativa evolução, sendo que a produtividade ultrapassou os $4.000 \mathrm{~kg} / \mathrm{ha}$ na safra 2016/17. Isso significa uma melhoria de quase $200 \%$ na produtividade no período sinalizado. Dessa forma, o crescimento da área plantada e a significativa melhoria na produtividade, sobretudo das culturas de soja e milho, são as razões principais pelas quais a produção de grãos no Mato Grosso e na região Centro-Oeste cresceram tanto nos últimos anos. Sobre a evolução da produção de grãos, em milhões de toneladas, tanto para o estado do Mato Grosso quanto para a região Centro-Oeste, apresenta-se a seguir a figura 03. 


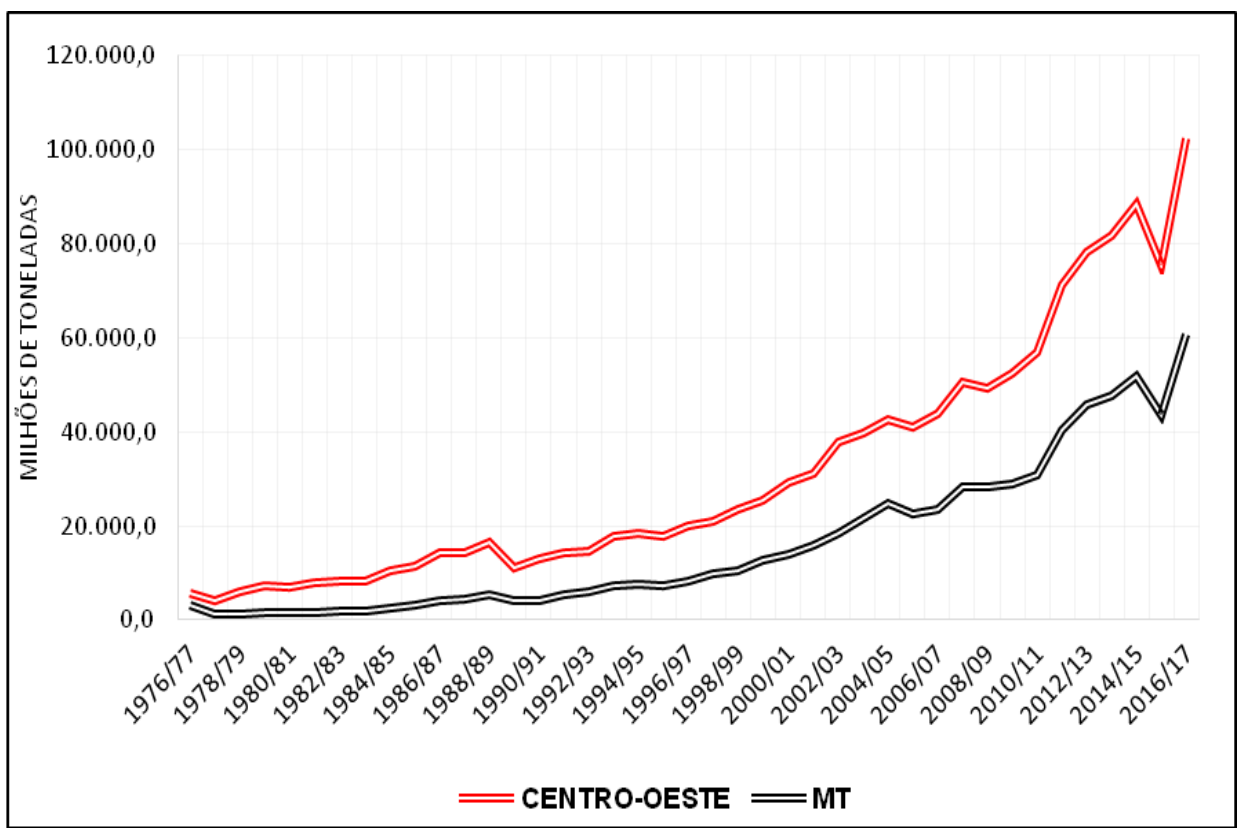

Figura 03: Série histórica da produção de grãos no estado do Mato Grosso e na região CentroOeste em milhões de toneladas (safra 1976/77 a 2016/17).

Fonte: Conab, 2017. Elaborado pelo autor.

Os dados das figuras 01,02 e 03 permitem uma relação, pois, para analisar a quantidade produzida, por exemplo (figura 03), é preciso considerar a área plantada e a quantidade produzida por hectare, ou seja, a produtividade. Dessa forma, pode-se afirmar que o crescimento do número de hectares plantados e a evolução da produtividade dos grãos na região Centro-Oeste e no estado do Mato Grosso resultam nos 60 milhões de toneladas produzidos no estado do Mato Grosso (safra 2016/17), e nos mais de 100 milhões de toneladas produzidos na região Centro-Oeste do Brasil. Com isso, a afirmação feita para a figura 01 de que o estado do Mato Grosso é responsável por $60 \%$ da área plantada de grãos na região Centro-Oeste também pode ser feita para a figura 03 , pois em torno de $60 \%$ da produção de grãos da região Centro-Oeste também ocorre no estado do Mato Grosso. Ademais, é interessante notar a queda de produção que ocorreu na safra (2015/16). Essa queda está atrelada à queda na produtividade dos grãos nesta safra, pois ao analisar a figura 01, não houve queda na área plantada de grãos na referida safra. Assim, a questão da produtividade se configura num elemento fundamental para a dinâmica produtiva do agronegócio de grãos da região Centro-Oeste e do estado do Mato Grosso.

Com a apresentação desses dados, outro ponto que vale a pena salientar é a importância de ter um conjunto de dados que possa contemplar um período amplo para análise, pois com um período restrito, considerando hipoteticamente apenas as últimas 
cinco safras, por exemplo, não seria possível afirmar que houve um crescimento importante na área plantada, produtividade e produção dos grãos no estado do Mato Grosso e na região Centro-Oeste.

As culturas de soja e milho possuem uma representatividade maior - sobretudo no que se refere a área plantada e quantidade produzida na última safra - nos dados apresentados nas figuras 01 e 03. Na área plantada do estado do Mato Grosso, considerando a safra 2016/17, a cultura do milho e da soja representam em torno de $95 \%$ do total, enquanto na região Centro-Oeste as duas culturas representam em torno de $90 \%$ do total. Considerando a produção em toneladas, levando em conta, do mesmo modo, a safra 2016/17, no estado do Mato Grosso as culturas de milho e soja representam em torno de $98 \%$ do total de grãos produzidos no estado, enquanto na região Centro-Oeste essa porcentagem também é de aproximadamente $98 \%$. Dessa forma, importa identificar qual o destino da produção de soja e milho produzidos no estado do Mato Grosso. O destino desses dois principais produtos está vinculado a um sistema técnico complexo que opera no território, mesmo que a maioria seja destinada à exportação (figuras $01 \mathrm{e}$ 03), pois envolve complexos de transporte, armazenagem e processamento dos grãos. Assim, visando apreender melhor essa complexidade territorial preconizada pelo agronegócio dos grãos (Santos e Silveira, 2001), apresentam-se as figuras 01 e 03, de modo que se possa entender para onde vai a produção de soja (figura 01) e milho (figura 03) do estado do Mato Grosso.

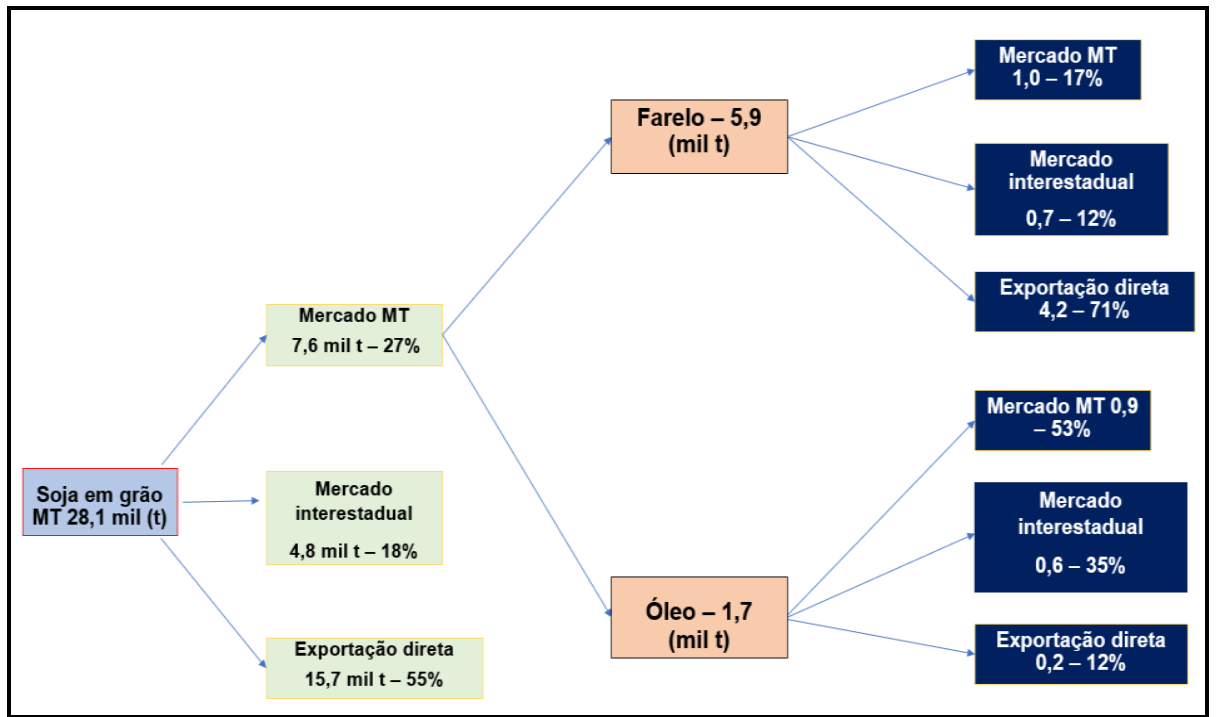

Figura 04: Destino da produção de soja em Mato Grosso - safra 2015/16².

Fonte: Imea, 2016. Elaboração do autor (2018).

\footnotetext{
${ }^{2}$ A elaboração da figura 01 foi realizada com base nas pesquisas fornecidas pelo Instituo Mato-grossense de Economia Agrícola sobre o destino da produção da soja no estado do Mato Grosso na safra 2015/16.
} 
Na figura 04, o primeiro ponto que merece destaque, e não é novidade, é fato de mais da metade 55\% da soja produzida em Mato Grosso ser exportada diretamente. $18 \%$ da soja colhida é vendida para outros estados brasileiros, e $27 \%$ da soja produzida em Mato Grosso permanece no estado e é transformada em dois principais derivados: farelo de soja e óleo de soja. Do total da produção de soja que permanece no estado do Mato Grosso, $77 \%$ é transformado em farelo de soja, e $23 \%$ é transformado em óleo de soja. Do total transformado em farelo de soja, 17\% abastece o mercado interno do Mato Grosso (em geral vai para granjas de suínos, frangos e bovinos), $12 \%$ é vendido para outros estados brasileiros, e $71 \%$ é exportado para outros países. Do total de óleo de soja produzido em Mato Grosso, 53\% abastece o mercado interno do estado, 35\% é vendido para outros estados brasileiros e $12 \%$ é exportado para outros países. Com isso, englobando soja em grão, farelo de soja e óleo de soja, pode-se dizer que pelo menos $65 \%$ da soja produzida no Mato Grosso é exportada para outros países. A grande maioria da soja mato-grossense exportada é feita sem adicionar valor ao produto, ou seja, é exportada em grão bruto.

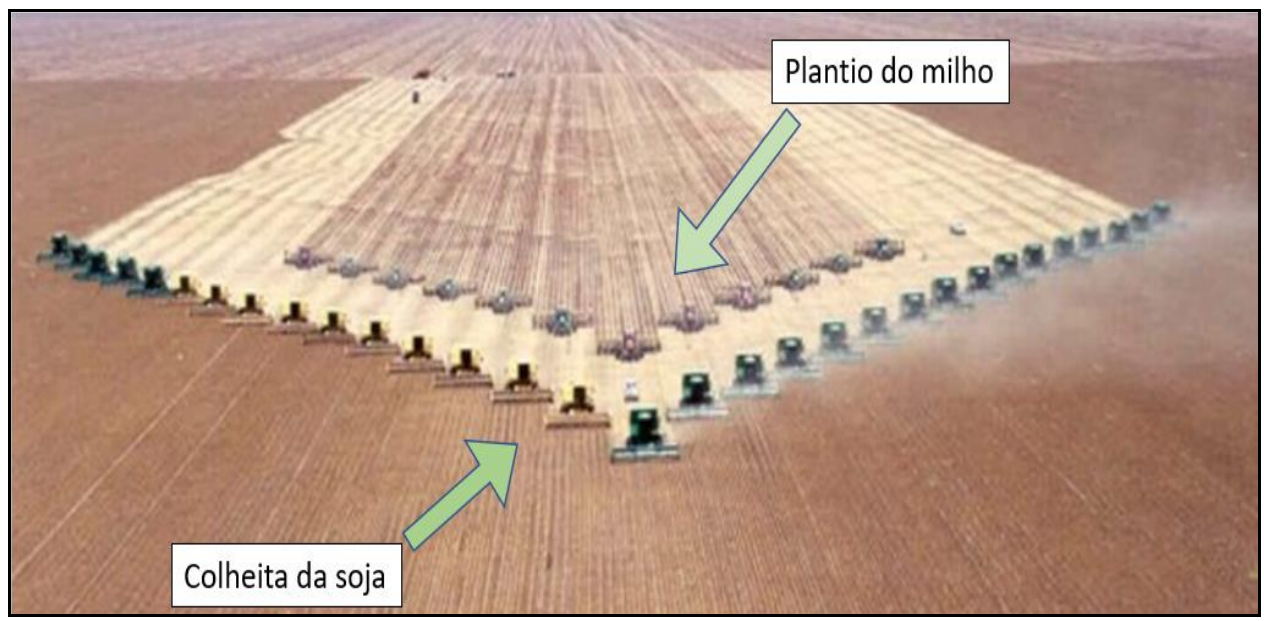

Figura 05: Colheita de soja procedido do plantio de milho em Sapezal/MT.

Fonte: Elaboração do autor (2018), a partir da foto de Leomar José Mess (2004).

$\mathrm{Na}$ figura 06 apresentamos o destino da produção de milho do estado do Mato Grosso, tendo também por base o resultado das pesquisas realizadas pelo IMEA na safra 2015/16. Vale lembrar que mais de $80 \%$ do milho produzido em Mato Grosso não é oriundo da primeira safra. Em geral, os agricultores cultivam a soja na primeira safra e em seguida plantam o milho, aproveitando o período de chuva que finda na época da floração do milho. Antes de analisarmos a figura 06, apresentamos a figura 05, que demonstra um exemplo do que normalmente ocorre nas grandes unidades produtivas do Mato Grosso, onde a colheita da soja é imediatamente acompanhada do plantio do milho. Essa é a chamada agricultura de precisão, na qual não se perde tempo e espaço 
para produzir. O plantio do milho, neste caso, é chamado de milho $2^{\mathrm{a}}$ safra, ou milho safrinha. A safra principal é a da soja. Mesmo assim, a produtividade do milho tem atendido satisfatoriamente às expectativas dos produtores nos últimos anos, tendo chegado, na safra 2016/17, segundo a Conab, a 120 sacas por hectare.

Na figura 03, a exemplo da figura 01, apresentamos o esquema sobre o destino da produção de milho do estado do Mato Grosso.

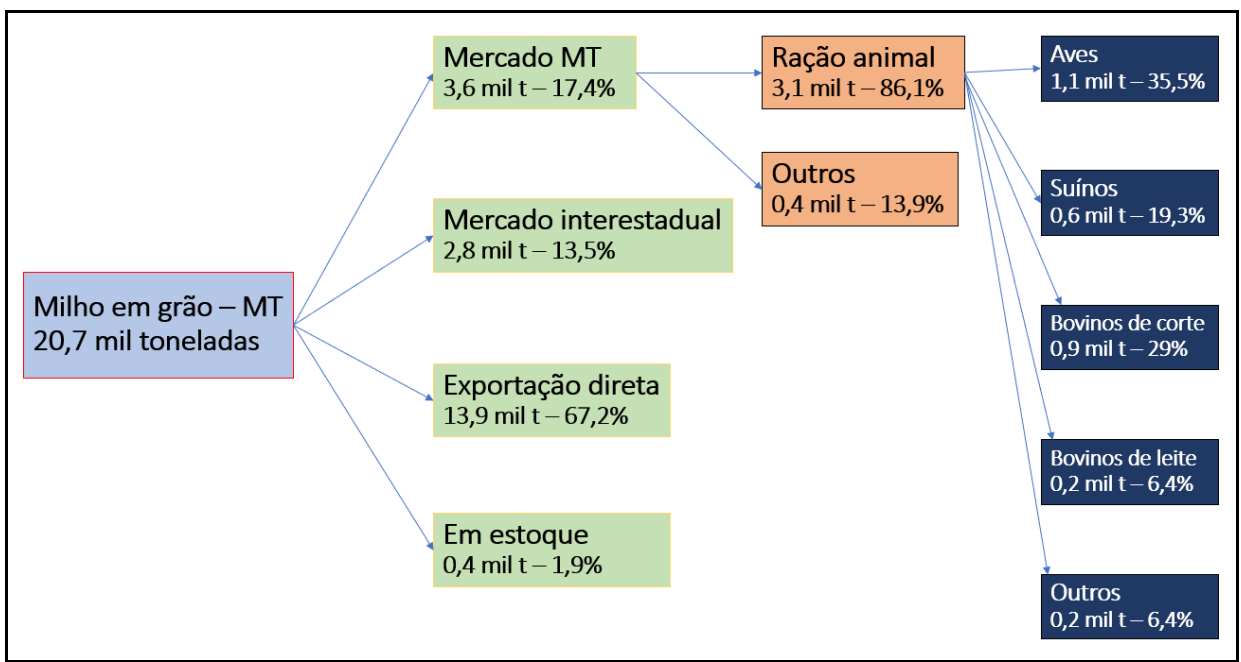

Figura 06: Destino da produção de milho em Mato Grosso - safra 2014/15.

Fonte: Imea, 2016. Elaboração do autor (2018).

De acordo com a figura 06, tendo por base a safra 2014/15, o estado do Mato Grosso produziu 20,7 milhões de toneladas de milho em grão. Desse montante, 13,9 milhões de toneladas $(67,2 \%)$ foram para exportação direta, 2,8 milhões de toneladas $(13,5 \%)$ foram vendidos para outros estados do Brasil, 0,4 milhões de toneladas $(1,9 \%)$ foram mantidos em estoque e, por fim, 3,6 milhões de toneladas $(17,4 \%)$ foram para o mercado interno do Mato Grosso. Do total de toneladas usadas no mercado interno do estado do Mato Grosso (3,6 milhões), 3,1 milhões $(86,1 \%)$ foi transformada em ração animal, e 0,4 milhões (13,9\%) foram para outros mercados. Dos 3,1 milhões de toneladas destinadas para ração animal, 1,1 milhões $(35,5 \%)$ foram para o segmento de aves, 0,6 milhões $(19,3 \%)$ foram para suínos, 0,9 milhões $(29 \%)$ para bovinos de corte, e 0,2 milhões para bovinos de leite $(6,4 \%)$. Além desses, 0,2 milhões $(6,4 \%)$ de toneladas foram destinadas como ração para outros tipos de animais.

Com os dados da figura 04 e da figura 06, confirma-se a ideia de Bernardes (2015), de que há uma lógica que integra a cadeia de produção de grãos e carnes no estado do Mato Grosso, assim como também ocorre em outros estados do Brasil. Do destino da produção de milho e soja, apesar da maioria dos grãos produzidos serem 
destinados à exportação, há um montante significativo sendo transformado em ração animal, confirmando-se a lógica de agregar valor ao produto ao transformar proteína vegetal (soja e milho - no caso do milho, vem sendo usado como fonte energética, largamente empregado na alimentação humana e animal, devido seu alto conteúdo de amido, disponível numa forma facilmente digerível e de baixo custo (Oliveira et al. 2004) em proteína animal (suínos, frangos e bovinos). Essa lógica tende a se concretizar e continuar crescendo na medida em que ações estratégicas dos agricultores e gestores públicos vão ao encontro da ideia de não exportar o produto bruto, tal como ele sai da lavoura, mas transformá-lo em outro produto que possa servir com maior aproveitamento e preço os mercados interno e externo. A instalação dos complexos agroindustriais nessas regiões (a BRF Brasil Foods em Lucas do Rio Verde) são exemplos dessa tendência que deverá privilegiar a transformação dos produtos primários, sobretudo soja e milho.

Dessa forma, há um sistema complexo entrelaçado que atua na produção dos agronegócios de grãos e carnes no estado do Mato Grosso. Esse sistema torna a dinâmica geoeconômica do agronegócio do Mato Grosso complexa de ser entendida, dada sua lógica econômica, política, financeira, empresarial, local e global, ocorrendo de forma contraditória e conflitante ao mesmo tempo.

Neste contexto, os dados sobre investimentos e produção da região CentroOeste e do estado do Mato Grosso podem ser relacionados às transformações que ocorrem e repercutem no território. O território, neste sentido, bem como apontam Santos e Silveira (2001), é usado a todo momento de maneira estratégica pelos grandes grupos empresariais, não apenas dos agronegócios de carnes, mas sobretudo os agronegócios de grãos, para manter os interesses hegemônicos no centro das ações realizadas sobre o território. Assim, as obras de engenharia e infraestrutura muitas vezes impressionam pela sua grandeza, com amplos e modernos complexos agroindustriais (como a área que compreende a agroindústria da BRF Brasil Foods - unidade Lucas do Rio Verde - figura 07), e pela sua perversidade, com uma parcela significativa da população vivendo em condições abaixo do que em geral a população da cidade vive. $\mathrm{Na}$ figura 05 pode ser observado uma parte do conjunto habitacional no qual vivem mais de 5 mil pessoas que trabalham na unidade da BRF Brasil Foods, de Lucas do Rio Verde.

Como aponta Santos (2014), a exemplo do que é demonstrado nas figuras 07 e 08, é possível interpretar os fenômenos que ocorrem no agronegócio brasileiro na ótica da divisão social do trabalho. Trata-se também de uma divisão espacial do trabalho. Santos (2014) assevera que isso é válido tanto para a escala mundial quanto para a escala local. Sempre que existirem complexos industriais, independentemente se forem atrelados ao agronegócio, existirá a conjugação do que se denomina de divisão social e espacial do trabalho. Neste sentido, os setores de uma indústria, como a que aparece na figura 08, são divididos e subdivididos de acordo com o grau de instrução e exigência que existe em cada departamento da indústria. Da mesma forma, a figura 08 demonstra um complexo habitacional para trabalhadores de baixa renda da BRF Brasil Foods, entende-se que um bom número de trabalhadores dessa empresa recebe um baixo salário, 
dado o cenário da figura 08 sobre o conjunto habitacional. No entanto, não quer dizer que não tenha uma parcela de trabalhadores com melhor remuneração e consequentemente, vivendo em locais de outro padrão social.

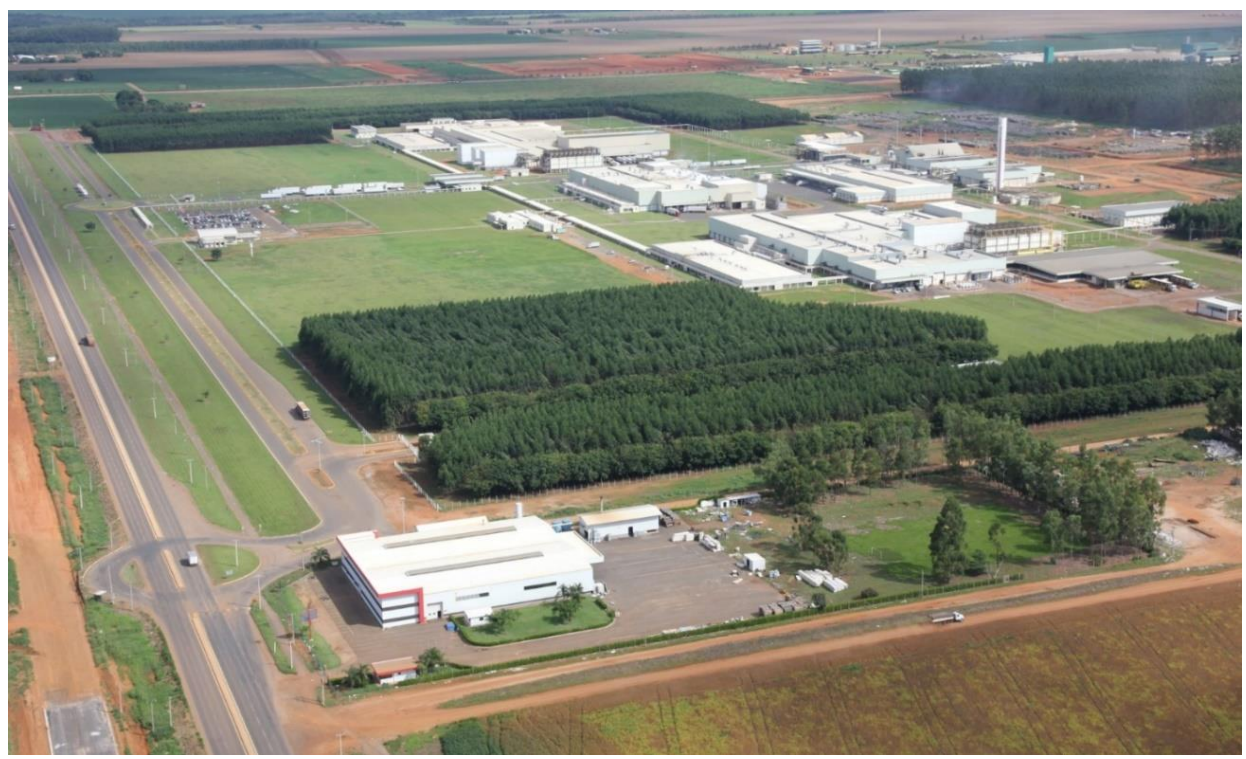

Figura 07: Vista aérea da área que compreende o complexo agroindustrial da BRF Brasil Foods unidade Lucas do Rio Verde/MT.

Fonte: Prefeitura Municipal de Lucas do Rio Verde/MT (2016).

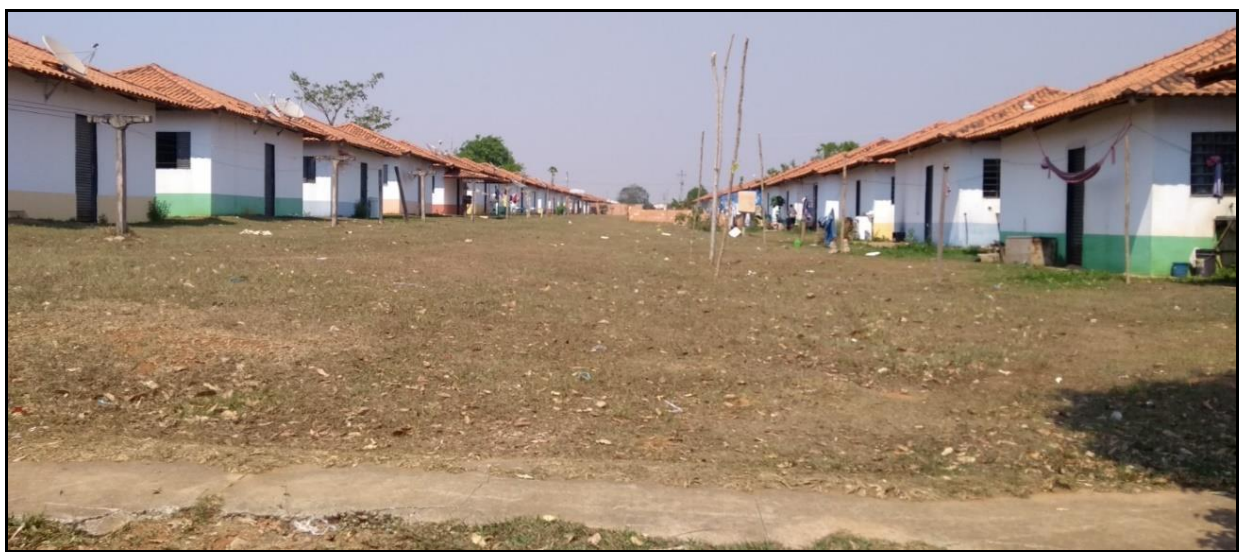

Figura 08: Conjunto habitacional que abriga os trabalhadores da BRF Brasil Foods - Unidade Lucas do Rio Verde/MT.

Fonte: Foto do autor (2017). 
Portanto, dados os avanços e as perspectivas de desenvolvimento que a região Centro-Oeste e o estado do Mato Grosso alcançaram, é importante frisar que o modo capitalista de produção, que perpassa pelas esferas dos setores do agronegócio, cria e recria condições para manter ou aprofundar características visíveis da divisão social e espacial do trabalho (SANTOS, 2014), bem como da desigualdade social que cresce e se confirma nesses espaços. Com isso pode-se entender como se dá o processo de formação da divisão social e territorial do trabalho Santos (1977), que na verdade, também remonta ao processo histórico de constituição social e econômica desses lugares, inseridos em um contexto nacional.

Há, portanto, uma lógica que entrelaça o agronegócio e as cidades do estado do Mato Grosso a ser apreendida, pois a todo tempo a interdependência entre agronegócio e cidade está presente. Nesta perspectiva, no próximo tópico discutiremos sobre a relação do agronegócio com as cidades do Mato Grosso.

\section{O agronegócio do Mato Grosso em paralelo com a cidade}

O estado do Mato Grosso, dotado de uma complexidade de arranjos espaciais produtivos que se devem em boa medida ao agronegócio, imprime no espaço geográfico relações entre campo e cidade que necessitam de maior atenção para ser compreendido. A compreensão dessa relação não ocorre em separado do potencial da produção agrícola do estado do Mato Grosso já demonstrado no tópico anterior.

Cassiolato e Lastres (2003) afirmam que a definição de arranjos produtivos se refere a um conjunto de agentes econômicos, políticos e sociais localizados no mesmo território, desenvolvendo atividades econômicas correlatas e que apresentam vínculos de produção, interação e cooperação. No entanto, o processo intrínseco nos arranjos espaciais produtivos, considera a formação social e econômica (Santos, 1977) de qualquer região na qual se possa identifica-lo, além das determinações de ordem organizacional que historicamente ocorrem nessa região, a atuação de grupos economicamente hegemônicos numa determinada região, bem como a divisão social e espacial do trabalho que pode ser identificada numa determinada região. Essas questões, inerentes aos arranjos espaciais produtivos, estão, na verdade, preocupadas em entender o processo que as constituem e que as fazem ser parte da peculiar relação existente entre o agronegócio e as cidades que estão no seu meio. Assim, ao adotarmos as definições de arranjo espacial produtivo de Cassiolato e Lastres (2003), acreditamos que elas estão intimamente ligadas com a relação do agronegócio com as cidades. Por essas razões, vale inferir que há diferentes atores que interferem e ao mesmo tempo contribuem para determinar as transformações que ocorrem no território. Entre os principais, destacamse:

i: atores econômicos (clientes, parceiros e competidores; fornecedores de insumos, componentes ou equipamentos; fornecedores de serviços técnicos); ii: atores do conhecimento (consultores, universidades e institutos de pesquisa); iii: atores de regulação (governos em seus vários níveis); iv: atores sociais 
(sindicatos associações empresariais, organizações de suporte e do chamado terceiro setor, entre outros) (CASSIOLATO e LASTRES, 2003, p. 22).

Dessa forma, a interconexão entre os atores que permitem a fluidez de atividades do agronegócio em paralelo com as funções da cidade faz com que todo um ambiente e toda uma estrutura sejam construídos e direcionados em vista de um funcionamento ajustado dos padrões de produção, tanto no campo (nas lavouras ou unidades produtivas agrícolas) quanto nas cidades (nos escritórios, indústrias, empresas, lojas, bancos, postos de combustível, centros administrativos - públicos e privados - , centros de ensino, postos de saúde, dentre outros). No entanto, é preciso cuidado ao estabelecer essas relações, pois, dada sua complexidade, o agronegócio, presente como atividade econômica majoritária na região de Lucas do Rio Verde e Sorriso ${ }^{3}$, e, portanto, indutor de lógicas de funcionamento do sistema agro urbano, não imprime, em todos os sentidos, a lógica de funcionamento das cidades ditas do agronegócio (Elias, 2011).

Essa tarefa complexa, confusa, e muitas vezes contraditória, de compreensão das relações entre agronegócio e cidade, exige uma flexibilidade no modo de entender a questão, haja vista que as cidades em si, mesmo que sejam comandadas pelas ações desencadeadas pelo agronegócio, possuem uma particularidade que denota o termo cidade. Exemplos como Lucas do Rio Verde e Sorriso, se encaixam nesse quadro. Em função dessa compreensão que confere um limite à influência do agronegócio na cidade, nota-se a necessidade de basear-se cautelosamente em Elias (2011). Para a autora, essas cidades são, na verdade, cidades do agronegócio, constituídas em "espaços urbanos inseridos em regiões produtivas agrícolas nos quais se dá a gestão local ou regional do agronegócio globalizado" (ELIAS, 2011, p. 161). A autora enfatiza ainda mais essa definição ao afirmar que "é possível identificar várias cidades, em diferentes partes do país, cuja existência, crescimento econômico e aumento da urbanização se devem diretamente à consecução do agronegócio globalizado" (ELIAS, 2011, p. 162).

Elias (2011) confere ao agronegócio uma responsabilidade sem precedentes ao apontar que esse ramo da economia é estritamente responsável pela dinâmica de cidades como Lucas do Rio Verde e Sorriso. Acredita-se, contudo, como apontado anteriormente, que essa definição precisa ser relativizada, pois o agronegócio não é a principal parcela da economia do estado do Mato Grosso - maior produtor nacional de grãos - tampouco da região Centro-Oeste. Sem dúvida a importância do agronegócio para cidades como Lucas do Rio Verde e Sorriso é inquestionável, e sem dúvida o agronegócio imprime no funcionamento da cidade uma lógica particular, atrelado a ele. Mas parece exagero apontar que a urbanização dessas cidades se deve apenas ao agronegócio, mesmo que, em muitas oportunidades, podem-se avistar cenários nos quais a cidade está contornada e inserida no contexto das atividades do agronegócio

Ademais, a ideia de cidades do agronegócio desenvolvida por Elias (2011), de certa maneira destrói a tese de que a modernização não incorporou mão de obra devido à

\footnotetext{
${ }^{3}$ Usa-se o exemplo dessas duas cidades pelo fato de ter ocorrido nelas a realização dos trabalhos de campo.
} 
mecanização. No entanto, sabe-se que a modernização da agricultura não só incorporou mão de obra como também transformou, no sentido do seu crescimento e desenvolvimento, cidades como Lucas do Rio Verde e Sorriso, que na sua dinâmica econômica principal tem o agronegócio como grande mentor. Portanto, o que concretamente pode ser apontado, é que a cidade compõe, faz parte da produção do agronegócio, mas é uma parte da cidade que está totalmente inserida no estabelecimento agrícola, ou seja, na produção do agronegócio. Assim, a urbanização, quando chega num determinado ritmo, desenvolve atividades próprias, que não podem estar constantemente sendo reduzidas às necessidades de movimento da dinâmica do agronegócio, até mesmo para os casos de Lucas do Rio Verde e Sorriso ${ }^{4}$, nas quais o agronegócio é o principal segmento econômico. Com isso, não descartada a importância do agronegócio, essas cidades estão, atualmente, contempladas por um patamar de complexidade de suas ramificações que vão além do agronegócio.

Cidades como Lucas do Rio Verde e Sorriso, embora não se tenha dúvida sobre a importância do agronegócio nelas, possuem uma trama urbana que abarca sua população, que não necessariamente é atrelada ao agronegócio. Na medida em que essas cidades cresceram, muito em razão da expansão do agronegócio, foram criando especificidades próprias, peculiaridades que são específicas da vida urbana. Ou seja, à medida que cresce a construção civil, o número de agências bancárias, de escolas, de hospitais, de postos de combustível, de lojas, de supermercados, de escritórios, dentre outros, cresce o número de pessoas que não precisam estar diretamente ligadas à unidade produtiva do agronegócio para sobreviver.

Por essas razões, pode-se afirmar que, quando cidades como Sorriso e Lucas do Rio Verde nasceram, provavelmente suas ligações com o agronegócio era mais direta do que é hoje - e com isso não se quer dizer que o agronegócio perdeu sua importância nessas cidades. No entanto, a partir do momento que essas cidades atingem e ultrapassam 50 mil habitantes, muitas características passam a ser específicas delas, porque a cidade cria e recria suas particularidades sociais e econômicas. Ainda assim, sabe-se da supremacia do agronegócio nesses centros urbanos. Na figura 09, é possível observar o crescimento da população ao longo do tempo em Lucas do Rio Verde e Sorriso.

\footnotetext{
${ }^{4}$ Segundo dados do IBGE (2016), o PIB de Lucas do Rio Verde é composto de 19,5\% da agropecuária, 29,9\% da indústria e $56,5 \%$ de serviços - incluindo administração, defesa, educação, seguridade social e saúde públicas. Já o PIB de Sorriso é composto de 26,6\% da agropecuária, 13,5\% da indústria e 59,7\% de serviços também incluindo administração, defesa, educação, seguridade social e saúde públicas. É notável que o agronegócio não se configura como a principal atividade econômica, segundo o IBGE (2016), em nenhum dos municípios mencionados. No entanto, tal como buscou-se argumentar no texto, há uma diversidade de (agro) indústrias e (agro) serviços, ou seja, indústrias e serviços - urbanos - ligados ao agronegócio, que não dispensam o papel fundamental do agronegócio no desempenho econômico desses municípios, e que, ao mesmo tempo, não se confirma, em termos de dados, a produção agropecuária como principal setor da economia de ambos os municípios. Portanto, ocorre uma maior complexificação das atividades locais para além da produção agrícola, apesar de haver uma imbricação de fenômenos que continuariam criando uma relação direta com o agronegócio.
} 


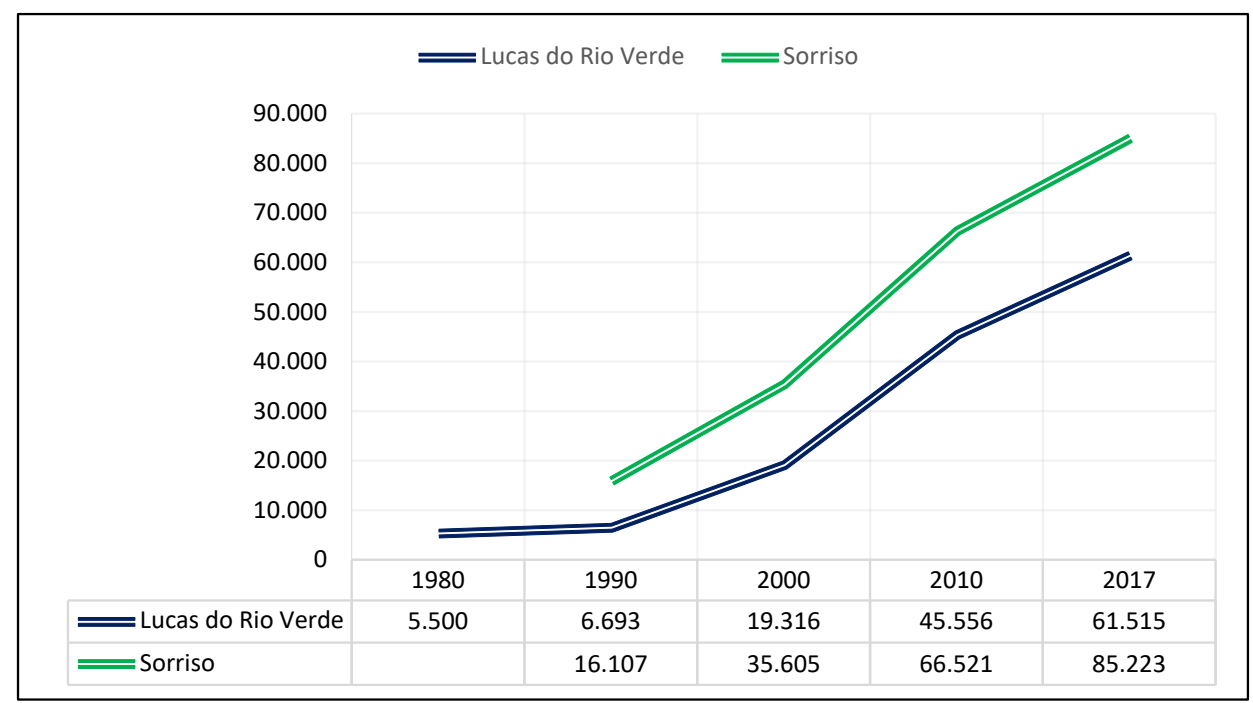

Figura 09: Evolução da população em Lucas do Rio Verde e Sorriso (1980-2017)5.

Fonte: Censo agropecuário do IBGE, 1990, 2000 e 2010.

Este crescimento da população, por sua vez, está ligado ao bom desempenho do agronegócio na região desses municípios nos últimos anos. Uma vez que as lavouras estão abertas, o intenso uso de tecnologia nas planas lavouras facilita o trabalho de plantio e colheita. De acordo com informações coletadas em trabalho de campo com um dos primeiros agricultores do município de Sorriso, desde que começou a plantar soja em Sorriso, de maneira mais intensiva a partir do final da década de 1980, apenas em uma safra as condições climáticas não colaboraram para o bom desempenho das lavouras. Segundo o agricultor, esse é um fator importante que atraiu população sulista para ampliar rapidamente as áreas plantadas de grãos.

Mais recentemente, depois dos anos 2000, a continuidade do crescimento populacional de Lucas do Rio Verde e Sorriso está relacionada ao crescimento da instalação de indústrias ligadas ao agronegócio, o que, por sua vez, intensifica a demanda por mão de obra e faz com que novos habitantes cheguem nestas cidades, agora não mais apenas habitantes oriundos do Sul do Brasil, mas das regiões Norte, Nordeste e Sudeste.

O crescente incremento populacional na região Centro-Oeste, estado do Mato Grosso, e cidades como Lucas do Rio Verde e Sorriso, em boa parte não se devem apenas ao bom desempenho do agronegócio nos últimos anos, mas também em função dos novos arranjos espaciais produtivos que vêm ganhando força na região Centro-Oeste como um todo. Neste aspecto, a instalação de novas indústrias e a ampliação do setor de

\footnotetext{
${ }^{5}$ Os dados de 2017 são estimativas do IBGE. Em 1980, segundo histórico do IBGE, Lucas do Rio Verde era distrito que pertencia ao município de Diamantino, e contava com cerca de 5.500 pessoas. Esse dado não foi encontrado para o caso de Sorriso, que antes de sua emancipação pertencia ao município de Nobres.
} 
serviços, juntamente com o agronegócio, têm sido os responsáveis principais pela atração de grandes contingentes populacionais.

Neste contexto, o estado do Mato Grosso, atualmente, é responsável por aproximadamente cerca de $22 \%$ da população da região Centro Oeste. Em função do estágio avançado dos novos arranjos espaciais decorrentes dos grandes investimentos no estado do Mato Grosso, a tendência é que o estado continue recebendo população oriunda de outras partes do Brasil, sobretudo por manter uma alta demanda por mão de obra na indústria e no setor de serviços, que muitas vezes estão atrelados ao agronegócio. Segundo o IBGE (2016), o estado do Mato Grosso, nos últimos cinco anos, foi o estado que manteve índices de crescimento acima de 5\% ao ano, sendo que, em algumas regiões do estado, como nas cidades de Sorriso e Lucas do Rio Verde, as taxas de crescimento se aproximam de $10 \%$ ao ano. Esse expressivo crescimento econômico, em boa parcela, está atrelado aos novos arranjos espaciais produtivos que surgem e se consolidam pelas regiões do estado e intensificam a relação do campo com a cidade, haja vista que cada vez mais um complementa o outro.

Os novos arranjos espaciais estão ocorrendo num estágio mais abrangente, ou seja, os investimentos feitos no Centro-Oeste como um todo vêm apresentando uma diversificação, devido às novas demandas apresentadas pela região e devido ao planejamento estratégico do governo (BNDES, 2014), para fazer a região despontar em outros segmentos econômicos. Há, no sentido dos novos arranjos espaciais produtivos, um dinamismo a ser apreendido. De acordo com o documento sobre a região CentroOeste apresentado pelo BNDES (2014), dentre os principais projetos industriais de impacto econômico e social na região estão: Fibria Celulose S. A., Eldorado Brasil Celulose S. A., Anglo American Níquel do Brasil, Votorantim Cimentos S. A., Votorantim Siderurgia S. A., e Petrobrás. Isso demonstra que, nos investimentos realizados nas indústrias de base do Centro-Oeste, estão segmentos ligados ao papel celulose, química e petroquímica, construção civil, sem contar os investimentos feitos na melhoria do sistema de transporte terrestre, energia e telefonia, terminais de armazéns, dentre outros, que fomentam o crescimento da economia ligada ao agronegócio.

Neste sentido, no estado do Mato Grosso, inúmeras cidades receberam investimentos significativos do BNDES, ligados a diferentes segmentos econômicos, como, por exemplo, Rondonópolis, Cáceres, Tangará da Serra, Primavera do Leste, Sinop, Alta Floresta, Confresa, Sorriso, Lucas do Rio Verde, Nova Mutum, dentre outras (BNDES, 2014). No contexto do recebimento desses investimentos, o agronegócio do estado do Mato Grosso, tendo em conta a importância que exerce para a economia e geração de emprego e renda para a população do estado, passou a estabelecer uma relação de complementariedade com as cidades, e não mais de disputa ou atraso, como tradicionalmente ocorreu quando se comparava às cidades maiores do Brasil com o campo (Corrêa, 1999).

Neste viés, os novos arranjos espaciais produtivos, tendo presente nos mesmos o cenário de produção do agronegócio do estado do Mato Grosso, se configuram em um dos principais fatores responsáveis pela organização produtiva do agronegócio em Mato 
Grosso, haja vista que a interação entre indústria, serviços e agronegócio se torna cada vez mais visível. Com isso, a demanda de recursos associados ao agronegócio é grande. Em regiões onde o agronegócio é o carro-chefe da economia, as cidades passaram a exercer papéis fundamentais para que o agro pudesse alcançar seu sucesso produtivo e organizacional. Em função disso, encontra-se na literatura definições como cidades do agronegócio (Elias, 2011), ou seja, aquelas cidades que têm seu crescimento atrelado ao agronegócio e que existem para atender demandas específicas do agronegócio, e não o contrário, como ocorreu em décadas anteriores, onde o campo existia para atender a cidade.

Assim, corrobora-se com estudos mais recentes, com o de Elias (2015), ao afirmar que, em diferentes partes do Brasil, é possível identificarmos processos de urbanização, reestruturação urbana, enfim, mutações nas cidades, associadas à expansão do agronegócio. Nos locais (regiões) onde isso acontece, os capitais, não necessariamente do agronegócio, "têm cada vez mais domínio sobre as terras agrícolas, a tecnologia de produção, a logística, os trabalhadores, as esferas locais de poder, entre outros" (ELIAS, 2015, p. 32).

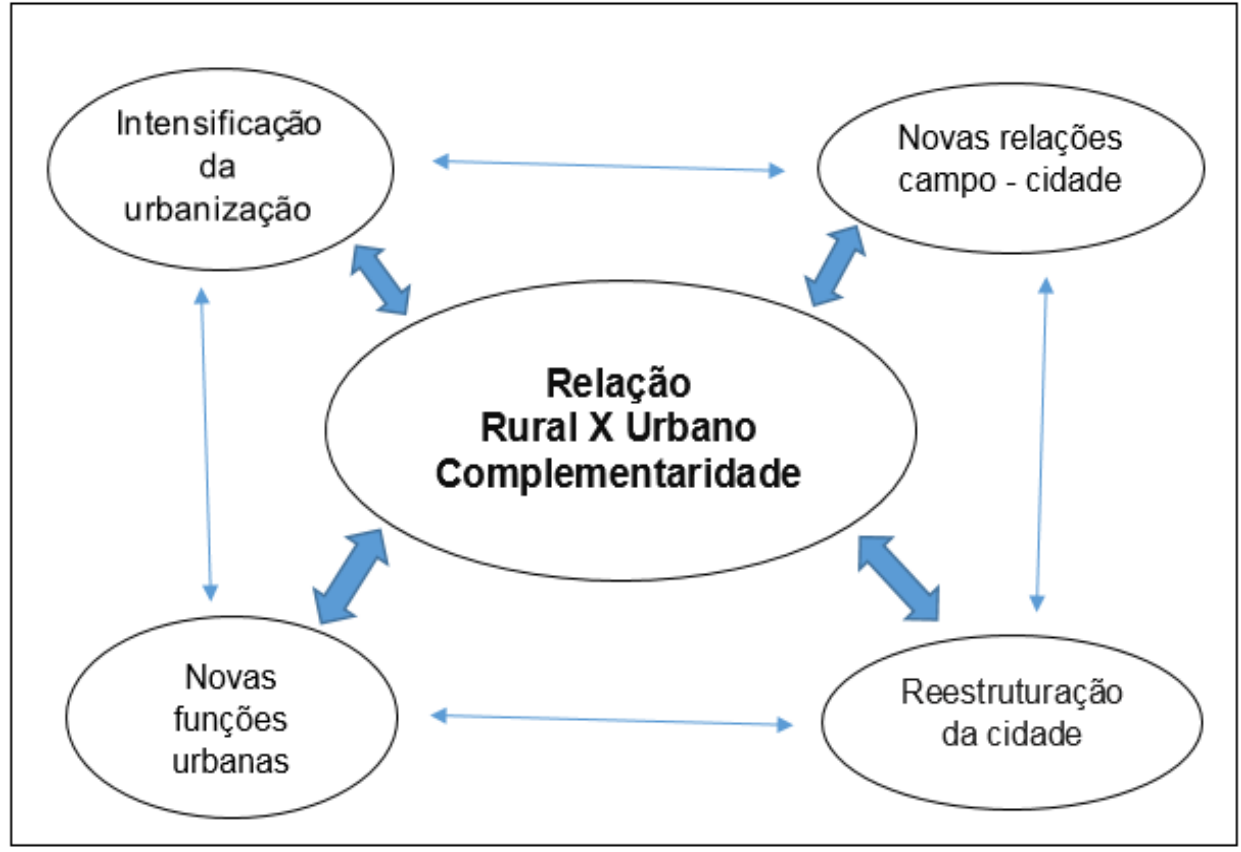

Figura 10: Processos presentes na relação agro urbana em regiões do agronegócio.

Fonte: Adaptado de Elias (2015). Elaborado pelo autor.

Por essas razões, torna-se cada vez mais necessário que a relação que pode ser identificada entre o agronegócio e as cidades seja uma relação de complementariedade 
(figura 10). Nessa relação, os processos urbanos se intensificam; a reestruturação da cidade, muitas vezes atrelada em grande parte à demanda do agronegócio, acaba ocorrendo; a cidade, por conta da forte presença do agronegócio no seu entorno, se especializa nas funções para o seu atendimento e intensifica-se. Assim, há uma relação (agro) urbana cada vez mais interconectada. Nessa relação, específica de cidades como Lucas do Rio Verde e Sorriso, não é possível imaginar as demandas do agronegócio sem a estrutura urbana que atende a essa demanda, assim como não é possível imaginar a cidade sem a presença do agronegócio. A figura 10 ilustra essa relação.

Portanto, os novos arranjos espaciais produtivos e as relações presentes, estabelecidas entre o agronegócio e as cidades, geram um conjunto complexo de atividades, que por momentos se entrelaçam entre cidade e agronegócio, por momentos são específicas das cidades e por momentos são específicas do campo - do agronegócio. No entanto, embora não se descarte essa importância e diferenciação, o que está claro é a relação de complementariedade presente entre o agronegócio e as cidades, e não de disputa ou de domínio de um sobre o outro.

\section{Considerações Finais}

A dinâmica produtiva da agricultura do estado do Mato Grosso é fortemente marcada pela produção de grãos. Os principais produtos dessa produção são as culturas de milho e soja, com destaque para a cultura da soja. Ao longo das últimas três décadas, viu-se os avanços na área plantada, produtividade e quantidade produzida de grãos no estado de Mato Grosso aumentar significativamente. Atualmente o estado do Mato Grosso planta em torno de 15 milhões de hectares de grãos, colhe em torno de 4 mil quilos de grãos por hectare plantado e chega a um montante de aproximadamente 60 milhões de toneladas de grãos colhidos.

A magnitude desses números é fruto de sucessivos investimentos realizados na agricultura do Mato Grosso nos últimos anos, além das condições naturais que permitiram esse rápido progresso. Em termos de investimento de capital é importante dizer que o Estado injetou de diferentes maneiras recursos visando o impulso do potencial produtivo do Mato Grosso. O Estado injetou dinheiro e fortaleceu a expansão do agronegócio através de políticas e programas como: Finame agrícola do BNDES, Sistema Nacional de Crédito Rural (SNCR), Polocentro, Prodecer, marcha para o Oeste, dentre outros (FREDERICO, 2008; BERNARDES, 2015; SILVA 2000; DENTZ, 2018). Ademais, através das pesquisas da Embrapa foi possível produzir com bons números a soja no Cerrado. O crédito subsidiado e os programas específicos para compra de maquinário agrícola, fertilizantes químicos, defensivos, sementes, silos, dentre outros, foram importantes para o alcance dos números demonstrados. Em termos de favorecimento das condições naturais, vale destacar o relevo totalmente favorável à mecanização nas áreas agricultáveis, os períodos de chuva bem definidos e a grande presença de luz solar - fator principal para o bom desenvolvimento das lavouras cultivadas. 
As culturas de soja e milho representam mais de $90 \%$ do total de grãos produzidos no estado do Mato Grosso (Conab, 2016). No entanto, como demonstrado ao longo do artigo, a maioria dessa produção - ao todo em torno de $60 \%$ - é destinada à exportação direta. Com isso, pode-se dizer que os ganhos deixam de ser maximizados, pois essa produção exportada de forma bruta poderia ser processada e vendida depois com ganhos ainda maiores. No entanto, sabe-se que essa questão é complexa, pois a grande quantidade de grãos exportada está relacionada aos interesses das tradings, o que impede que essa seja uma questão puramente interna, mas sim de um complexo sistema comercial mundializado. Por outro lado, pelo fato de maior parte da produção ser exportada, não quer dizer que o consumo interno deixa de ter sua importância, mesmo que a maior parte seja exportada. No caso da soja, em torno de $30 \%$ da produção é comercializada com outros estados do Brasil ou transformada para a criação animal. No caso do milho em torno de $40 \%$ da produção é consumida internamente - no estado do Mato Grosso e no Brasil. A porcentagem do milho que não é exportado é maior por conta de a maior parte da ração utilizada para a criação de suínos, aves e bovinos ser composta de milho.

Assim, nota-se que há uma integração das cadeias produtivas de grãos com as cadeias produtivas de carnes. Ao mesmo tempo, essa integração fortalece a importante relação que se confirma entre o agronegócio e as cidades do estado do Mato Grosso. Os complexos agroindustriais, por exemplo, estão instalados nas cidades, mas sobrevivem com a matéria-prima que chega do campo. Ademais, ao passo que as relações entre agronegócio e cidade se complementam, vão ganhando forma e força $o$ desenvolvimento, principalmente nas cidades, de padrões de vida desiguais.

Essa desigualdade é típica do desenvolvimento do agronegócio inserido no modo capitalista de produção. Os investimentos realizados no agronegócio, que acabam alavancando os indicadores produtivos e econômicos, são, na verdade, produtores do desenvolvimento desigual. Outrossim, a relação entre o agronegócio e as cidades que tanto buscamos entender, também é resultado desse modelo de desenvolvimento que acontece no capitalismo, de modo a atender interesses privados que sempre se recusaram a distribuir equitativamente os recursos econômicos gerados.

No entanto, ainda que seja totalmente pertinente e plausível fazer a crítica sobre esse modelo capitalista de desenvolvimento, a percepção de que o agronegócio não é mais submisso à cidade vem à tona. Em outras palavras, o que acaba se fortalecendo é uma relação de complementariedade entre agronegócio e cidade e não de submissão ou sobreposição de um em relação ao outro. Além disso, é preciso cautela ao dizer, tal como aponta Elias (2011), que existem cidades no Brasil que se desenvolveram estritamente em função do desenvolvimento do agronegócio. Como explicado, a partir do momento em que as cidades atingem um grau de complexidade, muitas de suas atividades começam a se desenvolver em função daquilo que é específico de uma cidade. Postos de gasolina, postos de saúde, escolas, dentre tantos outros serviços que estão concentrados nas cidades, vão aumentando não em função das atividades do agronegócio, por exemplo, mas em função do fato de as cidades estarem, dentro de tudo 
o que as compreende, demandando esses serviços. É nesse contexto que o agronegócio deve ser entendido na sua relação com a cidade.

Com isso, não se quer dizer que o agronegócio é menos importante para o desenvolvimento das cidades. Sempre foi e continua sendo importante, ainda mais no estado do Mato Grosso. Mas o que predomina é uma relação de complementariedade entre eles, em grande medida, fruto dos arranjos espaciais produtivos, que imprimem, tanto no espaço urbano quanto no agronegócio, uma nova ordem organizacional. As cidades, neste sentido, vão se confirmando como centros coordenadores das atividades que acontecem no agronegócio.

\section{Referências Bibliográficas}

BERNARDES, Júlia Adão. Novas fronteiras do capital no Cerrado: dinâmica e contradições da expansão do agronegócio na região Centro-Oeste, Brasil. Scripta Nova, v. xix, n. 507, p. 1-28, Barcelona: Universidad de Barcelona, 2015. Disponível em: <http://revistes.ub.edu/index.php/ScriptaNova/article/view/15112>. Acesso em 20 jul. 2018.

BNDES. Um olhar para o desenvolvimento: Centro-Oeste. Rio de Janeiro, BNDES, 512p. 2014. Disponível em:

<https://web.bndes.gov.br/bib/jspui/handle/1408/2881>. Acesso em 18 ago. 2018.

CASSIOLATO, J. E.; LASTRES, M. H. O foco em arranjos produtivos e inovativos locais de micro e pequenas empresas. In: LASTRES, M. H.; CASSIOLATO, J. E.; MACIEL, M. L. (Org.). Pequenas empresas: cooperação e desenvolvimento local. Rio de Janeiro: Relume Dumará, p. 21-34. 2003.

CONAB. Anuário da soja. 2017. Disponível em: < https://www.conab.gov.br/infoagro/safras>. Acesso em 3 jun. 2018.

CORRÊA. Roberto Lobato. O espaço urbano. 4.ed. São Paulo: Ática, 1999.

DENTZ, Eduardo Von. Dinâmica espacial da acumulação de capital do agronegócio: o caso do Mato Grosso. 2018. 201 f. Dissertação (Mestrado em Geografia) - Universidade Estadual do Oeste do Paraná, Francisco Beltrão, PR. Disponível em: < http://tede.unioeste.br/handle/tede/3731>. Acesso em 6 mai. 2018.

ELIAS, Denise. Agronegócio e novas regionalizações no Brasil. Revista brasileira de estudos regionais. V. 13, N. 2, p. 153-167, 2011. Disponível em: < http://rbeur.anpur.org.br/rbeur/article/view/400>. Acesso em 8 mai. 2018.

ELIAS, Denise. Reestruturação produtiva do agronegócio e novas regionalizações no Brasil. In: ALVES, Vicente Eudes Lemos (Org.). Modernização e regionalização nos Cerrados do Centro-Norte do Brasil. Ed. - Rio de Janeiro: Consequência Editora, 2015 (p. 25-44).

FREDERICO, Samuel. O Novo Tempo do Cerrado: Expansão dos Fronts Agrícolas e Controle do Sistema de Armazenamento de Grãos. 1. ed. São Paulo: AnnaBlume, 
2008. Disponível em: < http://www.teses.usp.br/teses/disponiveis/8/8136/tde-20032009163452/pt-br.php>. Acesso em 23 abr. 2018.

GRAZIANO DA SILVA, José. A nova dinâmica da agricultura brasileira. 2 ed. Unicamp, 1998.

IBGE. Censo Agropecuário. 2010. Disponível em: 〈https://censo2010.ibge.gov.br〉. Acesso em 18 jun. 2018.

IBGE. Produto Interno Bruto dos Municípios. 2016. Disponível em: <https://sidra.ibge.gov.br/tabela/5938\#resultado>. Acesso em 16 dez. 2018.

IBGE. Estimativas da agropecuária. 2016. Disponível em: < https://www.ibge.gov.br/estatisticas-novoportal/economicas/agricultura-epecuaria/levantamento-sistematico-da-producao-agricola>. Acesso em 23 jul. 2018.

IMEA. Boletim anual. 2016. Disponível em: <http://www.imea.com.br/imeasite/relatorios-mercado>. Acesso em 24 jun. 2018.

OLIVEIRA, J. P.; CHAVES, L. J.; DUARTE, J. B.; BRASIL, E. M.; FERREIRA JUNIOR, L. T.; RIBEIRO, K. O. Teor de proteína no grão em populações de milho de alta qualidade protéica e seus cruzamentos. Pesquisa Agropecuária Tropical (UFG), Goiânia-GO, v. 34, n.1, p. 49-55, 2004. Disponível em: https://www.revistas.ufg.br/pat/article/view/2341>. Acesso em: 14 dez. 2018.

SANTOS, Milton. Sociedade e Espaço: a formação social como teoria e como método. In: Boletim Paulista de Geografia, São Paulo, v. 54, jun. 1977 (p. 81-99).

SANTOS, Milton. Técnica, espaço, tempo: globalização e meio técnico-científicoinformacional. São Paulo: Hucitec, 1994.

SANTOS, Milton. Da totalidade ao lugar. São Paulo: Editora da Universidade de São Paulo, 2014.

SANTOS, Milton; SILVEIRA, Maria Laura. O Brasil: Território e Sociedade no Início do Século XXI. São Paulo, Editora Record, 2011.

SILVA, Lilian Leandra. O papel do estado no processo de ocupação das áreas de cerrado entre as décadas de 60 e 80. Revista on line Caminhos de Geografia. N.

1. $2^{\mathrm{a}}$ série. Pag. 24-36, UFU. Dez/ 2000. Disponível em:

<http://www.seer.ufu.br/index.php/caminhosdegeografia/article/viewFile/15251/8552〉. Acesso em 15 dez. 2018.

Este artigo foi desenvolvido com apoio financeiro da Coordenação de Aperfeiçoamento de Pessoa de Nível Superior (Capes). 


\section{Eduardo von Dentz}

Doutorando em Geografia pela Universidade Federal de Santa Catarina, mestre em Geografia pela Universidade Estadual do Oeste do Paraná, campus Francisco Beltrão e graduado em Geografia pela Universidade Federal da Fronteira Sul, campus Chapecó.

Campus Universitário Trindade. Florianópolis - SC. CEP: 88040-970.

E-mail: eduardovondentz@hotmail.com

Recebido para publicação em setembro de 2018 Aprovado para publicação em abril de 2019 